\title{
Forecasting the BIST 100 Index Using Artificial Neural Networks with Consideration of the Economic Calendar
}

\author{
Şahin TELLi ${ }^{*}$ \\ Metin COŞKUN**
}

\begin{abstract}
Artificial Neural Networks (ANN) is an analysis method that mimics the operating principle of the human brain. The problem-solving skills and the high rate of success in solving complex problems of ANN, relative to the other traditional methods has made it a preference as well in the fields of finance and economics.

I used Feed-forward back-propagation ANN (BPN-ANN) similar to related studies to forecast the indices, and employed trial-and-error method for the parameters like number of layers and neurons at layers to reach the optimal ANN structure.
\end{abstract}

Extant literature has used important macroeconomic variables like inflation, interest rates and money supply to shape the future expected value of the dependent variables of the index. This study is followed a new and unique perspective from established literature to make use of the advantages of ANN to forecast on Turkish stock market index. Further, the study used the daily data between 29th July and 15th November of 2015 for BIST 100, including codified economic calendar events and major parities, dollar index and indices as variables. Due to the expected technical superiority of the system as a result of the nature of the variables to be used, a higher forecast performance is expected, even with the occurrence of events outside the scope, like important political developments. The expected results of this study, other than being an immense contribution to literature will be developed into an important tool that can be utilized by investors.

Among several models, 18-20-1 structured MLP has best explanatory level with $0.893 \mathrm{R}^{2}$ and 0.207 MSE values. This was followed the 18-16-1 structured MLP which had the minimum MSE as 0.025 and $0.88 \mathrm{R}^{2}$. These are models 1 and 2 respectively. It is also observed that ECE (Economic Calendar Events) and 'Other' variables have notable effects that explain on the fluctuation of the index. Similarly, the two variables have shown their significant in other models as well. Prediction of opening is more successful than closing. ECE has greater success forecasting open prices.

Key words: Explanations of Economic Data, Economic Calendar, Artificial Neural Networks, Investor Interpretations

Jel Codes: C 45, D53, G 17.

\footnotetext{
* Anadolu Üniversitesi, Sosyal Bilimler Enstitüsü, sahintelli@yahoo.com

** Assoc.Prof.Dr., Anadolu Üniversitesi, İIBF, İşletme, metincoskun@anadolu.edu.tr

Date of submission: 30.08 .2016

Date of acceptance: 23.11 .2016
} 


\section{INTRODUCTION}

The theories of effective markets and random walk imply that the that under the normal conditions the market has all the knowledge and it is not possible to predict the prices of any security with the help of any technique that depends on past prices. According to studies however, there is no fully effective market but a highly effective market is possible.

Prediction of the prices of the stocks is an age old desire with dreams of getting rich at the expense of the market, and an important subject of research, and successful forecasts will be an important milestone in the understanding of the nature of markets. For this reason, people are always on the look for ways to develop new tools or reach some new outputs. In this study I seek to attain new conclusions by using one of these tools and employing Artificial Neural Networks (ANN).

ANN is an analysis method that mimics the operating principle of the human brain. Physics, chemistry, biology, engineering, geology and many other fields benefit from the use of ANN. The problem-solving skills and the high rate of success in solving complex problems of ANN, relative to the other traditional methods has made it a preference as well in the fields of finance and economics.

The research in this are has led to the development of new approaches development of new disciplines. One of these disciplines is behavioral finance, whose subjects should be considered carefully to get clearly reflection of prices. Pricing is always being effected from new incoming data like meeting minutes, PMI data, speech or some other expected or non-expected data (not stated in economic calendar) like elections or occurrence of any terroristic events. Other than macroeconomic variables, traders use Economic Calendar Events (ECE) to get the right positions. This is based on the idea that the existence of an ECE means new information to the market, and new data means there the economy or monetary system will move in a particular direction. An example can be given by an FOMC (Federal Open Market Committee) meeting intended to make a decision on changes in the interest rates. This will cause a fluctuation in the markets interest rates by either increasing or reducing it, or by leaving unchanged. The market may take a different direction as a result of a data perception that is expected to cause real positive change and a mass movement in the market.

In this study the daily data between 29th July and 1st November seperated for trainingvalidation and the data between 1st November and 15th November of the current year is used for testing of BIST 100 opening and closing prices. As a method, Back-Propagation Feed-forward Neural Network is used in MATLAB.

ANN was used to analyze the short term effect of economic data on the market prizing, based on investors interpretations, and with considerations to the cases of "sell/buy expectations in the 
market”. In other words, the stated economic explanations are added to the ANN analysis as variables, while known economic variables are not applied as they represent past events. Additionally, since the value of this change will not alter the economy in one day, the market's reaction is only an expression of the future anticipation of the investors, based on their view of the economy. In terms of determining the direction of the capital flow, the reaction by the investors as initially expressed by some parities and indices are used as the variables.

From the examination of the extant literature, it is observed that the difficulties encountered in obtaining some of the necessary monthly data (variables) and related restrictions act as a limiting factor in the application of ANN in analyses. In similar studies or studies in related fields (those done on stock market indices or exchange rates), for instance, important macroeconomic variables like inflation, interest rates and money supply have been used in the shaping of the future expected value of the dependent variables of the index. This study followed a new and different perspective from that in the established literature, thereby making use of the advantages of ANN to try forecasting Turkey's stock market index.

\section{LITERATURE REVIEW}

Artificial neural networks (ANNs) have been used for years in many fields as they proved their skills to solve problems even in cases of fuzzily or incomplete data (Fadlalla \& Amani 2014, p. 211). ANNs are software designs which are inspired by biological neural networks (Akay \& Gökdemir 2015, p. 386). In other words, ANNs are non-linear (Merh 2013, p. 22) computational techniques similar to the organization of brain cells in operation and structure (Hamid \& Habib 2014, p. 40). Thus, they have the ability to learn from examples or experiences (Ataseven 2013, p. 104). Basically, the structural approach to ANN has the following three elements; (Chen et al. 2013, p. 136137)

- Artificial Neurons

- Layers

- Network

\section{II.I. Artificial Neurons (Processing Elements-PEs)}

These are basic processing elements in the ANN structure which are also called nodes or neurons (Siddiqui \& Abdullah 2015, p. 40). All these nodes have synapses or connections to other neurons in the network in order to perform their tasks, and each connection has a weight to show the importance of each data to be used during learning. The process in a neuron is such that; 
- first; it receives various data, which is then summed by their weights by an adder function present at the nueron, secondly,

- if the weighted data is above a specific level, an output is generated and transfered to other neurons (Unlu et al. 2009, p. 38).

An adder function calculates net input value of a neuron by generally multiplying input values by their own weights as seen in the formula below; (Aygören et al. 2012, p. 78)

Net $=\sum_{i=1}^{n} W_{i} I_{i}$

Where, $\mathrm{W}_{\mathrm{i}}$ is the weight of $\mathrm{i}^{\text {th }}$ neuron, $\mathrm{I}_{\mathrm{i}}$ is input value that comes from $\mathrm{i}^{\text {th }}$ neuron and $\mathrm{n}$ is number of total nodes that connect to the $\mathrm{i}^{\text {th }}$ node.

The results obtained from the computation by the adder function are then inputed into an activation function. The activation function produces output of the neuron. It is important to choose the right function depending on the nature of the problem (Aygören et al. 2012, p. 78; Tosunoğlu \& Benli 2012, p. 543). The activation function does not need to be the same for all neurons in an ANN (Aygören et al. 2012, p. 78). In the context of this study, Hyperbolic tanjant, sigmoid and linear functions are the most commonly used activation functions by most scholars.

\section{II.II. Layers}

ANN has different layers -input layers, hidden layers and output layers- which consist of neurons that have operationally different missions (Siddiqui \& Abdullah 2015, p. 40). ANN may also be referred to by the number of its layers; if there are no hidden layers, it is known as a one layered neural network, whereas the presence of more than one layer implies the existence of at least one hidden layer and thus is known as a multi-layered neural network (Aygören et al. 2012, p. 78). As can be understood from the foregoing, ANN may have just one input layer and an output layer, but the number of hidden layers is dependent on the user. In other words, there may be one or more, or no hidden layers at all in an ANN (Fadlalla \& Amani 2014, p. 211; Siddiqui \& Abdullah 2015, p. 40).

\section{A) Input Layer}

This layer has neurons which have the sole responsibility of receiving data and transmit it to the next layer (Ataseven 2013, p. 103). In this layer, no processing operation is executed on the data received (Yakut et al. 2014, p. 141; Ekinci et al. 2008, p. 22).

B) Hidden Layer 
As it is mentioned above, there may be more than one hidden layers. In this layer(s) (located between input and output), neurons have a task of measuring the incoming data before transferring to the next layer (Siddiqui \& Abdullah 2015, p. 40). In case of multiple hidden layers, normally only the last hidden layer of the neuron has connections to the output layer (Karymshakov \& Abdykaparov 2012, p. 235). Extant studies show that even working with a single hidden layer is enough to get efficient predictions (Jin \& Kim 2015, p. 9).

\section{C) Output Layer}

This is the layer that provides the results of the problems that have been presented to ANN to the user (Aygören et al. 2012, p. 78).

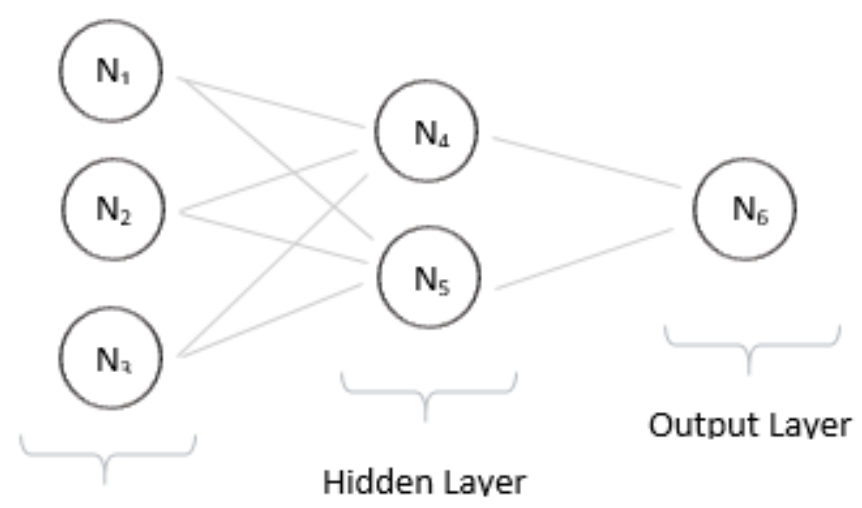

Input Laver

A typical layer order: $N_{i}$ are neurons stated in layers.

\section{II.III. Network}

There are different types of networks depending on the direction of flow of signals i.e. Feedforward and Feed-back networks (Ulusoy 2010, p. 23). In the Feed-forward network, information flow is on just one way, from input layer to output layer (Ulusoy 2010, p. 23). This type of network is preferred by most users due to its success with classification and estimation problems (Akay \& Gökdemir 2015, p. 387). For Feed-back networks, there can be information flow back to a neuron (Ulusoy 2010, p. 23).

Multilayer Perceptron (MLP) is the most common Feed-forward network type which is used for prediction (Akel \& Karacameydan 2012, p. 89). In MLP, there is at least one hidden layer between the input and output layers (Akcan \& Kartal 2011, p. 33). 


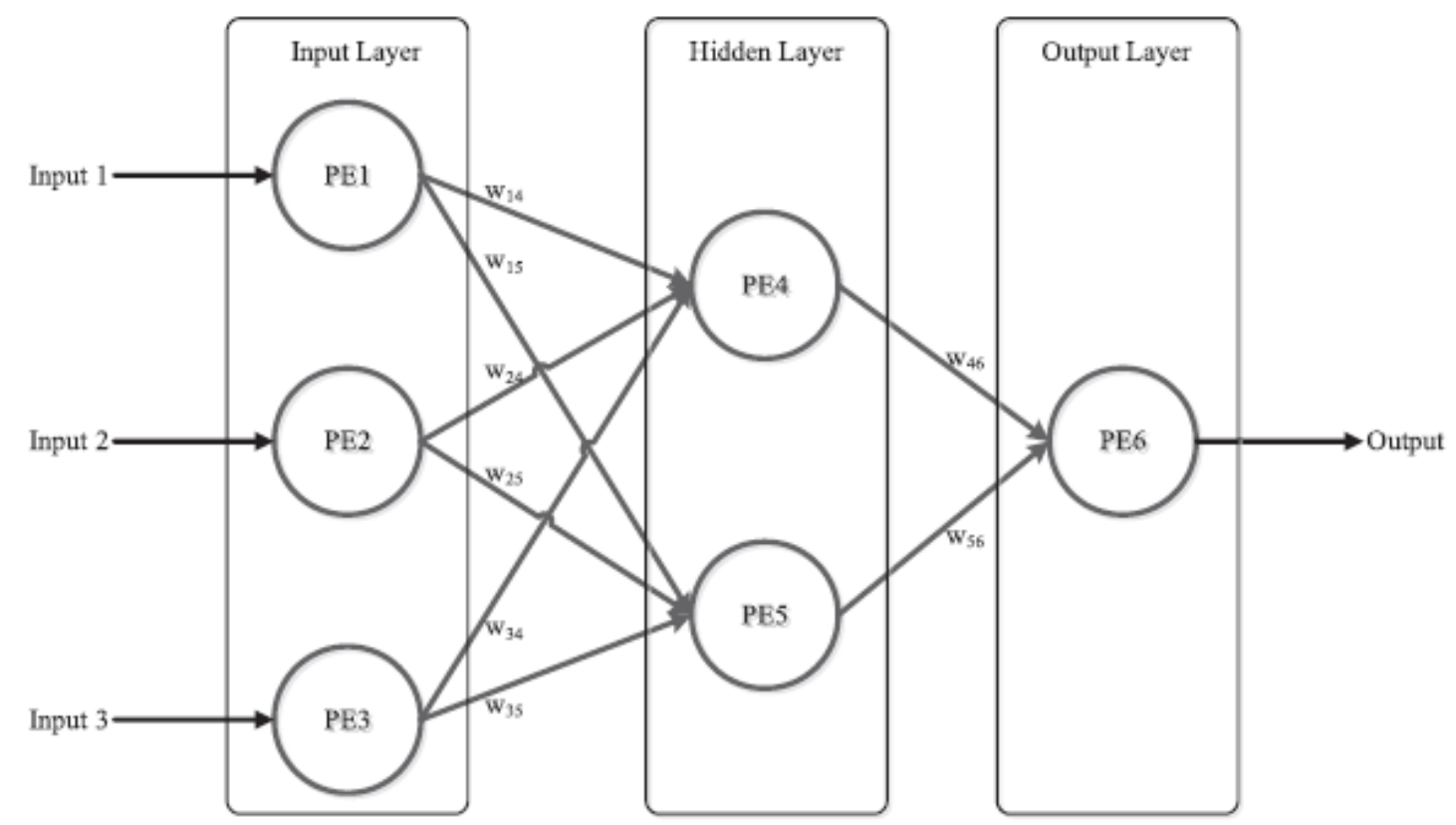

An example of a simple Feed-forward network structure: “PE”"s are processing elements of layers and “w”s are weights of the PE's. The direction of Information flow is shown by the pointed arrows.

Source: Fadlalla \& Amani 2014, p. 211

The Fundamental skill of an ANN is its learning capability (Akel \& Karacameydan 2012, p. 89). The learning process is so similar to that of a human being i.e. ANNs experience and learn from their mistakes too (Karymshakov \& Abdykaparov 2012, p. 235). On the other hand, there are two strategies for training networks i.e. supervised and unsupervised (Ataseven 2013, p. 104).

In supervised learning, networks generate outputs and make comparisons between these outputs and the actual observations. The difference between these comparisons is referred to as an error, and with iterations and by changing the weights these errors could be reduced to their minimum level (Ataseven 2013, p. 104). For unsupervised learning this process doesn’t include comparison of generated output and observed data (Ulusoy 2010, p. 24). The weights are ordered by the network itself (Tosunoğlu \& Benli 2012, p. 543). That means, in near future computers can learn without the help of human (Ataseven 2013, p. 106). In MLP networks, back-propagation algorithm is utilized for training of the network (Siddiqui \& Abdullah 2015, p. 40). In many studies back-propagation algorithm is found as the most effective as it requires less memory capabilities and reaching desired acceptable error levels in less time (Karymshakov \& Abdykaparov 2012, p. 235).

Aygören et al. (2012), looked at BIST 100 between 27 July 1995 and 29 July 2010 in their study using interest rates on deposits, gold prices, USD closing prices and interbank transactions datas as their variables. They used Feed-forward back-propagation network and defined their optimal network structure for the problem as 4-20-1. By using hyperbolic tanjant and linear function as 
activation functions in order for hidden layer and output layer respectively, ANNs demonstrated better performance than Newton Numerical Search Models and traditional time series models.

Yakut et al. (2014) conducted their study on BIST 100 between 2005 and 2012. They created models differentiated from each other by variables which included; one, two and three days lagged values of the indice, USD exchange rate, overnight interest rate, indices of Nikkei, BOVESPA, FTSE, CAC, DAX and dummy variables for days in a week. 3-4-1, 8-4-1 and 13-4-1 structered MLP networks were tried with tanjant sigmoid and linear activation functions for hidden layer and output layer respectively. They found that ANN has a better performance than Support Vector Machines method. Also, they concluded that a model that includes one day lag values of the index is more successful than models that include two and three day lag values of the index. Additionally they concluded that indices and variables of days in a week have an effect on the index.

Benli and Tosunoğlu (2012), worked on Morgan Stanley Capital International (MSCI) Index of Turkey between December 1987 and August 2008. There are twelve variables presented to a Feedforward network, and an optimal structure was reached at 12-11-1 by using the sigmoid activation function. The study implied that MSCI Turkey Index can be predicted by ANNs successfully and also that ANNs quickly catch changes in the trend of the studied index.

Akcan and Kartal (2011) tried to predict seven insurance sector companies’ shares which are available to trading on BIST Insurance Index between 01 March and 30 April in different time periods. They made estimations for 15 days, one month, one and a half months and two months time horizons using various macro and micro variables including closing prices of BIST100, CPI, TCMB effective selling USD dollar exchange rate, TCMB daily gold prices and ratios that concern firms like price/earnings rate. Using MLP neural network, 12-16-1 network structure is reached as the optimal network structure. In hidden layer tanjant hyperbolic function whereas in the output layer linear tanjant hyperbolic function are used as transfer functions. The results showed ANN as successful at predicting stock prices in BIST Insurance Index and optimal results are obtained in short time periods. Among many models, acceptable and effective results are mostly reached at 15-day periods while two of the models gave one month period.

Akel and Karacameydan (2012) studied net asset values of mutual funds in Turkey for January 2001 and December 2008. In this research 6 macro variables were used; USDTRY exchange rate, wholesale price index, BIST 100 indice, money supply, industrial production index and active bond interest rate. Hyperbolic tanjant and sigmoid functions are stated as activation functions for hidden layer asnd output layer respectively. As a conclusion it is implied that ANN is successful than 
Regression analysis. In is observed that the network successfully understood the effects of crisis on the 2001 in turkey and the global crisis of 2008.

Toraman (2008) used MLP to predict shares of two big companies from iron-steel sector using data between 31 December 2002 and 30 December 2007. The variables used in the models for each company include; interest rates (FED benchmarrk interest rate, interest rates on deposits 3-month), TCMB effective selling USD dollar exchange rate, CPI, gold prices and some micro economic variables on firms. As an activation function, hyperbolic tanjant was used in hidden layer and linear tanjant for the output layer. He concluded that ANN is a successful prediction tool but with less success during perceived quick changes in trends as well as in cases low volatility.

Kutlu and Badur (2009) used Feed-forward network with sigmoid activation function to predict the closing values of next trading day of BIST index between 2 July 2001 and 13 July 2006. The variables used include; Dummy variables for days, one day lagged values of the indices (BIST, NASDAQ, Dow Jones, S\&P 500 and indices of Brazilian, English, French, German and Japan markets), USD exchange rate and overnight interest rate. The best results were obtained with a model that included one day lag values of indice, USD exchange rate and overnight interest rates. Dummy variables and other markets had no meaningful effect on the BIST. And also, when compared to moving averages method, ANNs were found to be more successful in generating more accurate signals.

Ulusoy (2010) studied the direction and weekly closing prices of BIST index using data between 1997 and 2000. His variables included; USD exchange rate, BIST 100, interest rates (1-3-612 months), S\&P and NYSE indexes, gold prices and overnight interest rate. Analysis was done using a back-propagation Feed-forward network and sigmoid activation function. As a result, ANN has much more successful predictions on BIST at times when there are no extraordinary rises and drops in prices and political occurrences.

Siddiqui and Abdullah (2015) tried to predict the “CNX Nifty 500”. They used USD-INR exchange rate, crude oil price and major stock indices of USA (S\&P 500), Euro Zone (Euro Stoxx 50), China (Shanghai Composite Index) and Japan (Nikkei 225) as their independent variables. And, by using foreign markets they take benefit to identify market sentiments which happened overnight. They work with the daily data from January 2004 to December 2013 and employ the hiperbolic tanjant as the activation function. As conclusion they show that working with four major indices is better than using the two macroeconomic variables of Brent Crude and USDINR rate, because the effect of these variables is reflected on the index itself. 
The study by Fadlalla and Amani (2014) sought to predict closing prices of next day of Qatar Stock exchange by technical indicator variables. They used MLP as the network type for the study based on the data between 3 January 2010 and 31 December 2012. The optimal network structure is reached as 10-6-1. They used hyperbolic tanjant and identity functions respectively as the activation functions used in hidden layer and output layer. They concluded that ANNs have greater performance than the well-established autoregressive integrated moving average models in prediction.

Erilli et al. (2010) predicted inflation rates for twelve months with ANNs and hybrid neural networks using data from February 2003 to June 2008. The results concur with similar previous studies, and hybrid ANN models are more successful than known ANNs.

Karahan (2015) predicted export quantity, Akçalı (2015), the MIST financial pressure index, Ünlü et al. (2009), long time returns of first public offer, Ekinci et al. (2008), firm success/failure at economic crisis, Benli and Y1ldiz (2014), gold prices, and Ataseven (2013) sales volume of four products of a firm.

\section{METHODOLOGY}

In this study, data was obtained in four stages due to the separation of the data items into Parities, Indices, Economic Calendar Events (ECE) and Others.

- Parity data includes USDTRY exchange rates and other major exchange rates including EURUSD and USDJPY and Dollar index. These data was obtained from a Forex Company operating in Turkey.

- The Indices group contains data from the major indices from the developed world and others which may direct influence on the Turkish economy or afffect the BIST 100 index. These include Shanghai, DAX, Dow Jones, Euro Stoxx, FTSE, MICEX, NASDAQ, Nikkei, NYSE, S\&P. Additionally, one day lag values of closing prices of daily BIST 100 can be considered in this group. The values for these indices was obtained from Investing.com.

- ECE, as mentioned above, is the encoded data indicating whether an economic calendar event is affects BIST 100 “ 1 ”, or not “ 0 ”. Many events on the calendar have a value of “ 1 ”, but the main events can be ordered as; CPI (Consumer Price Index), PPI (Producer Price Index), PMI (Purchasing Managers Index), GDP (Gross Domestic Product) or speeches by FOMC Members ${ }^{\dagger}$. The economic calender used for the coding process was borrowed from Investing.com.

\footnotetext{
${ }^{\dagger}$ An extract of the list of the events is included in the appendix
} 
- Also included in the data a important daily occurances and news developments that have the potential of affecting the BIST 100. The impact of these events may either be positive or negative but must be strong enough like terrorist events, elections, coalition meetings and other political developments as well as news events from different countries that are not included in the economic calendar but which trigger anxiety and fear on growth expectations or devaluations or crisis.

In this study the daily data between 29th July and 1st November seperated for trainingvalidation and the data between 1st November and 15th November of 2015 is used for testing of BIST 100 opening and closing prices. The Back-Propagation Feed-forward Neural Network (BPN-ANN) method is used in MATLAB. To specify the structure of the network I decided to employ just one hidden layer and using trial and error method to reach the optimal neuron number for the hidden layer. Additionally, Sigmoid transfer function was adopted as the activation function at the hidden layer and linear transfer function at the output layer. The measure of performance is determined by the R2 and Mean Squared Error (MSE) results.

\section{III.I. Opening}

There are two packages to help explain the forecast success at the opening of BIST. The contents of the packages are as follows:

Package 1: USDTRY + EURUSD + USDJPY + DXY + Shanghai + Shanghait-1 + Nikkei + Nikkeit-1 + DAX $_{\mathrm{t}-1}+$ Djonest $-1+$ Estoxx $_{\mathrm{t}-1}+$ FTSE $_{\mathrm{t}-1}+$ MICEX $_{\mathrm{t}-1}+$ NASDAQt $_{\mathrm{t}-1}+\mathrm{NYSE}_{\mathrm{t}-1}+\mathrm{S}_{\mathrm{AP}} \mathrm{t}-1+$ BIST $_{\mathrm{t}-1}$

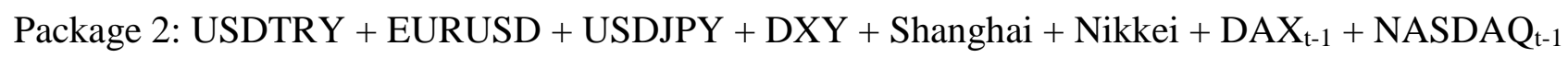
+ BIST $_{\mathrm{t}-1}$

USDTRY, EURUSD, USDJPY, DXY are taken as the difference in value between the present and the previous day's values i.e. value at “t-1" time (closing previous day) and “ $t$ ” time (opening present day) to reflect changes overnight.

Shanghai is the percentage change between the closing price of the previous day and opening price of the present while Shanghait-1 is 1 day lag value of Shanghai Composite Index. Nikkei is the percentage change between the closing price of the previous day and opening price of the present at the Nikkei 225 index while Nikkei $\mathrm{t}_{-1}$ is the 1 day lag value of Nikkei values. Similarly DAX $\mathrm{D}_{\mathrm{t}-1}$, Djonest-1, Estoxx $_{\mathrm{t}-1}$, FTSE $_{\mathrm{t}-1}$, MICEX $_{\mathrm{t}-1}, \mathrm{NASDAQ}_{\mathrm{t}-1}, \mathrm{NYSE}_{\mathrm{t}-1}, \mathrm{~S}_{\mathrm{AP}} \mathrm{P}_{\mathrm{t}-1}$ and BIST $_{\mathrm{t}-1}$ are one day lag values of the difference of close and open values at “t” at the DAX, Dow Jones, Euro Stoxx, FTSE, MICEX, NASDAQ, NYSE, S\&P, BIST 100 respectively. 
The models constructed using the packages for forecasting opening value of an index include.

Model 1: O_ECE + Package 1

Model 2: O_O + Package 1

Model 3: O_ECE + O_O + Package 1

Model 4: Package 1

Model 5: O_ECE + Package 2

Model 6: O_O + Package 2

Model 7: O_ECE + O_O + Package 2

Model 8: Package 2

Where, O_ECE is the code for ECE events which are considered to affect at open values of BIST. O_O is the code for the other important developments which happened overnight.

\section{III.II. Close Time}

There are two packages to help explain forecast success at opening of BIST:

Package 1: USDTRY + EURUSD + USDJPY + DXY + Shanghai + Shanghait-1 + Nikkei + Nikkeit-1 $+\mathrm{DAX}+$ Djones + Estoxx + MICEX + NASDAQ + NYSE + S\&P + OC_BIST + BIST $\mathrm{t}-1$

Package 2: USDTRY + EURUSD + USDJPY + DXY + DAX + NASDAQ + BIST

USDTRY, EURUSD, USDJPY, DXY are the percentage difference between their respective values at 09:00 and 17:00 at “t” time to reflect intraday changes.

Shanghai is the percentage difference of close and open price and Shanghait-1 is 1 day lag value of Shanghai values. DAX, Djones, Estoxx, MICEX, NASDAQ, NYSE, S\&P and OC_BIST are the percentage difference of open values at " $\mathrm{t}$ " time and close values at the time " $\mathrm{t}-1$ " of their respective indices. Package 1 does not contain FTSE as due to the fact that the difference between opening and closing values is always zero. Finally BIST $\mathrm{t}_{\mathrm{t}-1}$ is 1 day lag values of the difference between closing and opening values at " $\mathrm{t}$ " time.

These are the models constructed for forecasting closing value of the index. 
Model 1: C_ECE + Package 1

Model 2: C_O + Package 1

Model 3: C_ECE + C_O + Package 1

Model 4: C_ECE + O_O + C_O + Package 1

Model 5: O_O + C_O + Package 1

Model 6: Package 1

Model 7: C_ECE + Package 2

Model 8: C_O + Package 2

Model 9: C_ECE + C_O + Package 2

Model 10: C_ECE + O_O + C_O + Package 2

Model 11: O_O + C_O + Package 2

Model 12: Package 2

\section{RESULTS and DISCUSSION}

According to Table 1, the models returns between 9 and 10 true signals out of 11 predictions at opening forecasts and also have a success rate of between 5/11 and 6/11 at closing forecasts.

\begin{tabular}{|l|l|}
\hline Prediction Target & Results \\
\hline Open & $9 / 11,10 / 11$ \\
\hline Close & $5 / 11,6 / 11$ \\
\hline
\end{tabular}

Table 1: Models Prediction Results

\section{IV.1. Results for Opening Based on the Models}

The table below shows the most successful models with regards to their $\mathrm{R}^{2}$ and MSE values.

\begin{tabular}{|l|l|l|l|l|l|l|l|}
\hline Model & Package & Structure & O_ECE & O_O & MSE & R & $\mathbf{R}^{\mathbf{2}}$ \\
\hline 1 & 1 & $18-20-1$ & 1 & 0 & 0.207 & 0.945 & 0.893 \\
\hline 2 & 1 & $18-16-1$ & 0 & 1 & 0.025 & 0.938 & 0.880 \\
\hline
\end{tabular}




\begin{tabular}{|l|l|l|l|l|l|l|l|}
2 & 1 & $18-17-1$ & 0 & 1 & 0.052 & 0.927 & 0.859 \\
\hline 3 & 1 & $19-20-1$ & 1 & 1 & 0.119 & 0.868 & 0.753 \\
\hline 4 & 1 & $17-18-1$ & 0 & 0 & 0.226 & 0.865 & 0.748 \\
\hline 5 & 2 & $10-9-1$ & 1 & 0 & 0.072 & 0.898 & 0.807 \\
\hline 5 & 2 & $10-12-1$ & 1 & 0 & 0.118 & 0.895 & 0.801 \\
\hline 6 & 2 & $10-10-1$ & 0 & 1 & 0.097 & 0.932 & 0.869 \\
\hline 7 & 2 & $11-11-1$ & 1 & 1 & 0.066 & 0.904 & 0.818 \\
\hline 8 & 2 & $9-9-1$ & 0 & 0 & 0.092 & 0.907 & 0.823 \\
\hline
\end{tabular}

Table 2: Successful Models in Prediction of BIST100 for Opening Values

Table 2 is a representation of the most successful attempts from each model. In model 1(constructed by O_ECE and Package1) for instance, the biggest $\mathrm{R}^{2}$ is $(0.893)$, whereas the other attempts in the same model returned $\mathrm{R}^{2}$ readings of 0.8 . On the other hand, considering the MSE results, the second model with the lowest reading (0.025) is still found among 0.8 and over group in the $\mathrm{R}^{2}$ results. This model has 18-16-1 structure and has second biggest $\mathrm{R}^{2}$ value after first model. It was constructed using the O_O and Package 1.

The most explanatory model is obtained by using O_ECE and Package 1 together which results into higher $\mathrm{R}^{2}$ values as in model 1, but we can still predict BIST 100 (albeit) at lower level of success but with less error using model 2. Model 2 one more reading above the $0.8 \mathrm{R}^{2}$ level. It may thus be considered that using O_O leads to consistent results if it does not arise from parameters of network. To support this idea is model 6 (constructed by O_O and Package 2) which has biggest $\mathrm{R}^{2}$ among models consists of Package 2 and has an MSE value smaller than 0.1.

Models constructed using both O_ECE, O_O and Package 2 provided more successful results on both MSE and $\mathrm{R}^{2}$. Models with Package 1 which have neither O_ECE nor O_O have the worst performance in the table. The results in the table represent only the highest $\mathrm{R}^{2}$ readings from that particular model. In trials with different number of neurons less successful results are reached.

On the other hand, in comparison of models which do not consists of both O_ECE and O_O, Package 2 has better success than Package 1. In other words, Package 2 has more explanatory and less error level. 
To the less successful models, the addition of some variables can naturally improve the level of success. By adding ECE for instance, the first model became most successful model. However this action leads to the decline in the rate of performance in package 2. With this regard, we can conclude that more variables are needed to better see the effects of O_ECE where Package 2 less variables to show the success of O_ECE. Similarly, O_O has shown consistent increase in the success rate of a model with both Package 1 and Package 2.

\section{IV.2. Results for Closing Based on the Models}

In comparison of Table 3 with Table 2, the closing predictions are less successful than the opening predictions. There is no result over $0.8 \mathrm{R}^{2}$, and Package 2 had better $\mathrm{R}^{2}$ results than Package 1 .

\begin{tabular}{|l|l|l|l|l|l|l|l|l|}
\hline Model & Package & Structure & C_ECE & O_O & C_O & MSE & R & $\mathbf{R}^{2}$ \\
\hline 1 & 1 & $18-18-1$ & 1 & 0 & 0 & 0.551 & 0.865 & 0.748 \\
\hline 2 & 1 & $18-18-1$ & 0 & 0 & 1 & 0.578 & 0.869 & 0.756 \\
\hline 10 & 2 & $11-11-1$ & 1 & 1 & 1 & 1.143 & 0.872 & 0.761 \\
\hline 10 & 2 & $11-10-1$ & 1 & 1 & 1 & 0.276 & 0.893 & 0.798 \\
\hline 8 & 2 & $9-10-1$ & 0 & 0 & 1 & 0.435 & 0.842 & 0.709 \\
\hline 12 & 2 & $8-10-1$ & 0 & 0 & 0 & 1.079 & 0.862 & 0.744 \\
\hline
\end{tabular}

Table 3: Successful Models in Prediction of BIST100 for Closing Values

In comparison of Table 3 with Table 2, the closing predictions are less successful than the opening predictions. There is no result over $0.8 \mathrm{R}^{2}$, and Package 2 had better $\mathrm{R}^{2}$ results than Package 1.

In Table 3, the biggest $\mathrm{R}^{2}$ (0.798) was obtained from the model 10 constructed using C_ECE, O_O, C_O and Package2. However, all the other attempts in the model had $\mathrm{R}^{2}$ under 0.7. The least MSE (0.276) is also obtained from the same model. This model has 11-10-1 structure.

The model with the highest explanatory level is obtained by using C_ECE, O_O, C_O and Package 2 together. And in the cases where Package 1 is used, C_O has more success than C_ECE.

When neither C_ECE, O_O nor C_O were used Package 2 was again more successful than Package 1. The models that include only Package 1 are not presented in the table because they have $\mathrm{R}^{2}$ under 0.7 in all the trials. Adding only C_ECE had positive effect on the results of package 1 but the opposite on Package 2 as observed in the opening values. 


\section{CONCLUSIONS and RECOMMENDATIONS}

Among several models, 18-20-1 structured MLP has best explanatory level with $0.893 \mathrm{R}^{2}$ and 0.207 MSE values. This was followed the 18-16-1 structured MLP which had $0.88 \mathrm{R}^{2}$ and the minimum MSE as 0.025. These are models 1 and 2 respectively. It is also observed that ECE and 'Other' variables have notable effects that explain on the fluctuation of the index. Similarly, the two variables have shown their significant in other models as well. Prediction of opening is more successful than closing. ECE has greater success forecasting open prices. It should not be surprising due to the fact that O_ECE generally consists of events from the USA and China and they cannot have reversal effects on the BIST 100. But the same is not true for C_ECE which take into consideration all the calendar events (during the opening hours) from inside Turkey, the European Zone and the USA and may affect the index in any direction.

This study has shown ECE as being a good explanatory variable and therefore needs further research as a way of improving prediction of performance. For sustainable, consistent and much more reliable results different variations of ECE can be executed. Additionally, different variables like oil prices, gold prices, technical indicators may added to increase the predictive value. One of the limitations of this study is the short time span considered. The period of the study could be extended and the frequency of data shortened to one hour or 15 minutes. Also, different parameters of ANN could be tried. 


\section{REFERENCES}

Akay, EC \& Gökdemir, T 2015, 'The Comparison of The Financial Failure with Artificial Neural Network and Logit Models’, Journal of Business, Economics \& Finance, vol. 4, no. 3, pp. 383400.

Akcan, A \& Kartal, C 2011, 'İMKB Sigorta Endeksini Oluşturan Şirketlerin Hisse Senedi Fiyatlarının Yapay Sinir Ağları İle Tahmini’, Muhasebe ve Finansman Dergisi, July 2011, pp. 27-40.

Akçalı, BY 2015, 'MIST Ülkeleri Finansal Baskı Endeksleri (FBE)'nin Yapay Sinir Ağları ve BoxJenkins Yöntemleriyle Tahmin Edilerek Finansal Krizlerin Öngörülmesi', Muhasebe Bilim Dünyası Dergisi, vol. 17, no. 2, pp. 347-384.

Akel, V \& Karacameydan, F 2012, 'Yatırım Fonları Net Varlık Değerlerinin Yapay Sinir Ağları Yöntemiyle Tahmin Edilmesi', Anadolu Üniversitesi Sosyal Bilimler Dergisi, vol. 12, no. 2, pp. 87-105.

Ataseven, B 2013, 'Yapay Sinir Ağları İle Öngörü Modellemesi', Marmara Üniversitesi Sosyal Bilimler Enstitüsü Öneri Dergisi, vol. 10, no. 39, pp. 101-115.

Aygören, H, Sarıtaş, H \& Moral1, T 2012, 'İMKB 100 Endeksinin Yapay Sinir Ağları ve Newton Nümerik Arama Modelleri ile Tahmini’, International Journal of Alanya Faculty of Business, vol. 4, no. 1, pp. 73-88.

Benli, YK \& Yıldız, A 2014, 'Altın Fiyatının Zaman Serisi Yöntemleri ve Yapay Sinir Ağları İle Öngörüsü’, Dumlupınar Üniversitesi Sosyal Bilimler Dergisi, no. 42, pp. 213-224.

Chen, JH, Diaz, JF \& Huang, YF 2013, 'High Technology ETF Forecasting: Application of Grey Relational Analysis and Artificial Neural Networks’, Frontiers in Finance and Economics, vol. 10, no. 2, pp. 129-155.

Ekinci, Y, Temur, GT, Çelebi D \& Bayraktar D 2008, 'Ekonomik Kriz Döneminde Firma Başarısı Tahmini: Yapay Sinir Ağları Tabanlı Bir Yaklaşım’, Endüstri Mühendisliği Dergisi, vol. 21, no. 1, pp. 17-29.

Erilli, NA, Eğrioğlu, E, Yolcu, U, Aladağ, CH \& Uslu, VR 2010, 'Türkiye'de Enflasyonun İleri ve Geri Beslemeli Yapay Sinir Ağlarının Melez Yaklaşımı İle Öngörüsü', Doğuş Üniversitesi Dergisi, vol. 11, no. 1, pp. 42-55.

Fadlalla, A \& Amani, F 2014, 'Predicting Next Trading Day Closing Price of Qatar Exchange Index Using Technical Indicators and Artificial Neural Networks’, Intelligent Systems in Accounting, Finance andManagement, no. 21, pp. 209-223.

Hamid, SA \& Habib, A 2014, 'Financial Forecasting with Neural Networks', Academy of Accounting and Financial Studies Journal, vol. 18, no. 4, pp. 37-55.

Jin, J \& Kim, J 2015, 'Forecasting Natural Gas Prices Using Wavelets, Time Series, and Artificial Neural Networks’, Plos One, vol. 10, no. 11, pp. 1-23. 
Karahan, M 2015, 'Yapay Sinir Ağları Metodu ile İhracat Miktarlarının Tahmini: Arıma ve YSA Metodunun Karşılaştırmalı Analizi', Ege Akademik Bakış, vol. 15, no. 2, pp. 165-172.

Karymshakov, K \& Abdykaparov, Y 2012, 'Forecasting Stock Index Movement with Artificial Neural Networks: The Case of Istanbul Stock Exchange’, Trakya Üniversitesi Sosyal Bilimler Dergisi, vol. 14, no. 2, pp. 231-242.

Kutlu, B \& Badur, B 2009, 'Yapay Sinir Ağları ile Borsa Endeksi Tahmini', İstanbul Üniversitesi İsletme Íktisadi Enstitüsü Dergisi-Yönetim, vol. 20, no. 63, pp. 25-40.

Merh, N 2013, 'Optimal Model Design of Artificial Neural Networks for Forecasting Indian Stock Trends: An Experimental Approach’, XIMB Journal of Management, vol. 10, no. 2, pp. 21-42.

Siddiqui, TA \& Abdullah, Y 2015, 'Developing A Nonlinear Model to Predict Stock Prices In India: An Artificial Neural Networks Approach’, The IUP Journal of Applied Finance, vol. 21, no. 3, pp. 36-49.

Toraman, C 2008, 'Demir-Çelik Sektöründe Yapay Sinir Ağları ile Hisse Senedi Fiyat Tahmini: Erdemir A.Ş. ve Kardemir A.Ș. Üzerine Bir Tahmin Uygulaması', Muhasebe ve Finansman Dergisi, no. 39, pp. 44-57.

Tosunoğlu, NG \& Benli, YK 2012, 'Morgan Stanley Capital International Türkiye Endeksinin Yapay Sinir Ağları İle Öngörüsü’, Ege Akademik Baklş, vol. 12, no. 4, pp. 541-547.

Ulusoy, T 2010, ‘İMKB Endeks Öngörüsü için İleri Beslemeli Ağ Mimarisine Sahip Yapay Sinir Ağ1 Modellemesi', International Journal of Economic and Administrative Studies, vol. 3, no. 5, pp. 21-40.

Ünlü, U, Yıldız, B \& Yalama, A 2009, 'İlk Halka Arzlarda Uzun Dönem Getirilerinin Tahmini: Yapay Sinir Ağları İle İMKB için Ampirik Bir Çalışma’, Ekonometri ve İstatistik, no. 10, pp. 29-47.

Yakut, E, Elmas, B \& Yavuz, S 2014, 'Yapay Sinir Ağları ve Destek Vektör Makineleri Yöntemleriyle Borsa Endeksi Tahmini’, Süleyman Demirel Üniversitesi Íktisadi ve Idari Bilimler Fakültesi Dergisi, vol. 19, no. 1, pp. 139-157. 


\section{Economic Calender Events Affecting Opening Prediction Coded as ' 1 '}

Turkey

\begin{tabular}{|l|l|}
\hline 09:00 & Trade Deficit (June) \\
\hline 09:00 & CPI (Monthly) (July) \\
\hline 09:00 & CPI (Annual) (July) \\
\hline 09:00 & PPI (Annual) (July) \\
\hline 09:00 & PPI (Monthly) (July) \\
\hline 09:00 & Industrial Production (Annual) (June) \\
\hline $09: 00$ & Unemployment Rate (May) \\
\hline $09: 00$ & GDP (Annual) (Second Quarter) \\
\hline
\end{tabular}

USD

\begin{tabular}{|l|l|}
\hline $20: 00$ & FOMC Statement \\
\hline $20: 00$ & Federal Budget Balance (Tem) \\
\hline $20: 00$ & FOMC Meeting Minutes \\
\hline $02: 20$ & FOMC Member Kocherlakota Speaks \\
\hline $08: 45$ & FOMC Member Williams Speaks \\
\hline $21: 55$ & FOMC Member Lockart Speaks \\
\hline $18: 25$ & FOMC Member Stanley Fischer Speaks \\
\hline $19: 10$ & FOMC Member Rosengren Speaks \\
\hline $20: 00$ & Beige Book \\
\hline $20: 00$ & FOMC Economic Projections \\
\hline $20: 30$ & Fed Chair Janet Yellen Speaks \\
\hline $21: 30$ & FOMC Member Bullard Speaks \\
\hline $02: 00$ & FOMC Member Brainard Speaks \\
\hline
\end{tabular}


China

\begin{tabular}{|l|l|}
\hline $03: 00$ & Manufactoring PMI \\
\hline $03: 00$ & Non-manufactoring PMI \\
\hline $03: 45$ & Caixin Manufactoring PMI \\
\hline $03: 45$ & Caixin Services PMI \\
\hline $04: 00$ & Exports (Annual) (July) \\
\hline $04: 00$ & Imports (Annual) (July) \\
\hline $04: 00$ & Trade Balance (July) \\
\hline $04: 00$ & CPI (Monthly) (July) \\
\hline $04: 00$ & CPI (Annual) (July) \\
\hline $04: 00$ & PPI (Annual) (July) \\
\hline $07: 30$ & Industrial Production (Annual) (July) \\
\hline
\end{tabular}

EUR

\begin{tabular}{|l|l|}
\hline $18: 00$ & ECB's Nowotny Speaks \\
\hline $19: 00$ & ECB President Draghi Speaks \\
\hline
\end{tabular}

Economic Calender Events Affecting Closing Prediction Coded as '1' Turkey

\begin{tabular}{|l|l|}
\hline $10: 00$ & Exports (Tem) \\
\hline $13: 30$ & End Year CPI Forecasts (August) \\
\hline $13: 00$ & One Week Repo Rate (August) \\
\hline $13: 00$ & Overnight Borrowing Rate \\
\hline $13: 00$ & Overnight Lending Rate (August) \\
\hline $10: 00$ & Budget Balance (July) \\
\hline $10: 00$ & Industrial Production (Annual) (September) \\
\hline
\end{tabular}


USD

\begin{tabular}{|l|l|}
\hline $14: 55$ & Red Book (Monthly) \\
\hline $14: 55$ & Red Book (Annual) \\
\hline $14: 30$ & FOMC Member Dudley Speaks \\
\hline $14: 30$ & Core CPI (Annual) (July) \\
\hline $14: 30$ & Core CPI (Monthly) (July) \\
\hline $14: 30$ & PPI (Annual) (July) \\
\hline $14: 30$ & PPI (Monthly) (July) \\
\hline $15: 15$ & Industrial Production (Monthly) (July) \\
\hline $16: 00$ & Existing Home Sales (July) \\
\hline $16: 00$ & Philadelphia FED Manufacturing Index (August) \\
\hline
\end{tabular}

China

\begin{tabular}{|l|l|}
\hline $15: 20$ & FDI (July) \\
\hline $12: 00$ & PBOC Deposit Rate \\
\hline $12: 00$ & PBOC Interest Rate \\
\hline $12: 00$ & PBOC Reserve Requirement Ratio \\
\hline
\end{tabular}

Europe

\begin{tabular}{|l|l|}
\hline $10: 00$ & ECB Economic Bulletin \\
\hline $13: 30$ & Publishes Amount of Monetary Policy Meeting \\
\hline $11: 00$ & Core CPI (Monthly) (July) \\
\hline $11: 00$ & Core CPI (Annual) (July) \\
\hline $11: 00$ & CPI (Annual) (July) \\
\hline $11: 00$ & CPI (Monthly) (July) \\
\hline $11: 00$ & GDP (2. Quarter) \\
\hline $11: 00$ & GDP (Annual) (2. Quarter) \\
\hline
\end{tabular}




\begin{tabular}{|l|l|}
\hline $15: 00$ & Eurogroup Meetings \\
\hline $11: 00$ & Trade Balance (June) \\
\hline $11: 00$ & Unemployment Rate (July) \\
\hline $11: 00$ & Retail Sales (Annual) (July) \\
\hline $11: 00$ & Retail Sales (Monthly) (July) \\
\hline $13: 45$ & Deposit Facility Rate \\
\hline $13: 45$ & Interest Rate Decision (September) \\
\hline $14: 30$ & ECB Press Conference \\
\hline
\end{tabular}

